\title{
The Internet and Economic Growth in Less-developed Countries: A Case of Managing Expectations? ${ }^{1}$
}

\author{
CHARLES KENNY*
}

ABSTRACT A discussion of the theory of technology and economic growth suggests potentially negative implications for the impact of the Internet on developing countries. Technology in general is undoubtedly central to the growth process, but economists define technology in very broad terms. The impact of any particular, invented, technology is likely to be small. This theoretical perspective is supported by the empirical evidence on the limited impact of past "information revolutions" on less-developed countries (LDCs) and the present impact of the Internet on advanced economies. Furthermore, LDCs appear ill-prepared to benefit from the opportunities that the Internet does present - they lack the physical and human capital, along with the institutions required, to exploit the e-economy. Finally, even optimistic forecasts of the Internet's global economic impact are small in scale compared with the challenge of development. This has significant implications for development policy.

\section{Introduction}

The hope is widespread that the Internet will provide a powerful new tool in the battle against global poverty. For instance, the G-8's recent Charter on the Global Information Society has declared:

Information and Communications Technology (IT) is one of the most potent forces in shaping the twenty-first century ... IT is fast becoming a vital engine of growth for the world economy ... Enormous opportunities are there to be seized and shared by us all.

$(\mathrm{G}-8,2000)$

To back these claims, there is mounting anecdotal, econometric and theoretical support for the role of information technology in growth and development. This paper does not dispute such evidence. Because of the scale of the improvement over previous communications tools, the Internet might have a significant impact on growth through better functioning of markets and firms. In addition, there are effects within the sector itself, in particular the impact of network externalities, whereby the value of a connection to a network such as the telephone or Internet rises as others join the network. The increasing power-to-cost ratios of computers has shown up significantly in US productivity figures. New businesses and jobs have been created, economies have gained, schools have acquired new pedagogical tools and non-governmental organizations

* Charles Kenny, Room F5K 114, The World Bank, 1818 H St NW, Washington, DC 20433, USA. 
(NGOs) and pressure groups have exploited the technology to further agendas. It is likely that this impact will grow world-wide.

This paper takes a slightly more sceptical look at the likely impact of the Internet on long-term economic growth rates in developing countries. It is, of course, too early for there to be any firm answers about the relationship between the Internet and economic development in LDCs, ${ }^{2}$ but likely orders of magnitude for such an impact can be suggested. The results are perhaps worrying for those who expect a strong stimulus to LDC growth from the application of ICT.

The paper is divided into four sections: a discussion of the theoretical role of technology in growth and the theoretical case for the Internet as a growth-inducing technology; evidence of the Internet's impact on growth rates in the USA and OECD; the appropriateness of the Internet as a growth-promoting technology for LDCs; and estimates of future impacts in LDCs and a look at the past impact of individual communications technologies on world-wide growth rates.

\section{Theories of Economic Growth: Does Technology Cause Growth? Is the Internet a Likely Candidate?}

The Internet is a highly efficient tool for transferring information-e-mail, for example, is cheaper than a telephone call, leaves an electronic record and can be "broadcast" simultaneously to many recipients. Further, the Internet is a technology which benefits from network externalities - my use of the system increases its value to others, by providing another partner in the web information transfer.

The Internet therefore appears a good candidate as a growth-promoting technology. As most recent theories of economic growth suggest a significant role for technological change (differing rates of broad technological adaptation are, for example, the driving force behind divergence in Romer's (1990) model), the impact of the Internet on growth might be substantial.

The definition of "technology" used by Romer or by growth accountants in general spreads far beyond "physical things that are invented", however. This is because the impact of "technology" is generally measured by total factor productivity (TFP). Growth accounting procedures measure increases in stocks of physical capital (the quantity of assets such as factories and roads measured by their dollar value), human capital (the education stock, usually measured by average years of schooling) and labour (measured in numbers of people of working age). The procedures then estimate how much output growth can be "expected" from such increases in capital and labour stocks. TFP is defined as the actual measured growth of output minus the growth rate expected from increases in capital and labour stocks. It is a measure of the efficiency with which capital and labour are combined to produce output, the residual from a growth accounting exercise. ${ }^{3}$

"Technology" as defined by growth accountants thus includes not just new products and processes but also "business technology" (management techniques and systems), "political technology" (forms of government and institutions) and "social technology" (modes of human interaction) - indeed, it includes everything that might affect output that is not physical (and sometimes educational) capital or labour. It includes such factors as market power, increasing returns, technical complementarities, excess capacity, unmeasured fluctuations in work effort and hours and other errors in measurement. Because "technology" as defined by the TFP approach is very broad, it might be that the effect of individual technological advances is small and/or that other types of technology are more important for growth than "formally" invented, embodied 
(physical), technologies such as the Internet. Romer argues that "technologies" such as Wal-Mart's management of inventory data—not invented by formal R\&D—are probably more significant than inventions such as the transistor (Perkins \& Perkins, 1999). The Internet may even have less impact than "just in time" management, for example. ${ }^{4}$

\section{Evidence on Computers, the Internet and Economic Growth in the USA and OECD}

This section briefly reviews the evidence linking the recent rise in TFP in the USA to the expansion in computer use and evaluates the likely future productivity impact of the Internet. It concludes that there is evidence of a link, but not of significant spillovers (outside the computer manufacturing sector).

At the micro level, Lehr \& Lichtenberg (1999) claim that there have been high returns to investments in computers across a range of industries compared to other types of capital (in the USA), especially in the presence of skilled labour. Some analysts argue that the impact of the IT revolution is at last beginning to be felt at the macro level. A recent "survey of surveys" (Pohjola, 1998) concluded that in the 1980s and the early 1990s, the consistent finding was that there was a broadly negative correlation between IT investment and economy-wide productivity in the USA. A few studies in the late 1990s began to reverse this conclusion. Some of the more optimistic studies looking at the 1996-99 period suggest that computer hardware was responsible for between 0.49 and $0.82 \%$ of US output growth in that period, and for a significant percentage of productivity improvements (Yusuf, 2000).

This evidence has, however, been disputed. "Excess" micro-level returns apparently disappear when other factors, including company reorganization, are taken into account (David, 2000). ${ }^{5}$ Gordon (2000) presents macro evidence that computers and the Internet do not cause a dramatic leap forward in productivity outside the durables manufacturing sector. He disaggregates the recent rise of $1.35 \%$ in US TFP growth into $0.54 \%$ of cyclical effects and $0.81 \%$ of trend growth accounted for by the durable manufacturing sector-including computers, peripherals and telecommunications. ${ }^{6}$ In the $88 \%$ of the private economy outside of durables, TFP growth has actually decelerated-suggesting that there is no evidence of a spillover effect from computers.

Looking at labour productivity over a longer span, IT-intensive industries outside the IT sector itself are among the worst performing. ${ }^{7}$ The USA's TFP change has averaged around $4 \%$ in mining over $1987-97$, compared to close to-4\% per year in the banking sector-this despite the fact that IT spending as a percentage of output was highest in banking amongst the industries covered and second lowest (after construction) in mining (The Economist, 23 September 2000). ${ }^{8}$ This suggests that the "Solow Paradox"-widespread evidence of computer use and little evidence of productivity growth-continues, at least in modified form.

Similarly, the share of ICTs in capital stock is significant in a number of other OECD countries, and yet they have seen no increase in productivity. Schreyer (2000) finds for the OECD that, as with the USA, ICT equipment has seen rapid improvements in the ratio of price to performance, with a significant subsequent substitution of ICT for other types of capital and labour inputs. ICT's share of the nominal productive capital stock has increased from 2.4 to $3.2 \%$ in France, 1.2 to $2.3 \%$ in Japan, and 3.6 to $5.2 \%$ in the UK in the $1985-96$ period (compared to 6.2 to 7.4 in the USA). However, there is no evidence in the 1985-96 period that there was the increase in TFP growth. The UK, with the second largest share of ICT in total capital stock behind the 
USA, has actually seen a productivity slowdown in the last few years (Bank of England, 1999).

Regarding the Internet in particular, the timing of the US productivity revival was too early to be accounted for by e-commerce (contra Nezu, 2000). In 1995, one estimate (from NUA, at www.nua.ie) suggests that sales generated by the World Wide Web in that year were only US $\$ 436$ million. Even in 1998 , e-transactions were only worth US $\$ 43$ billion (The Economist, 24 July 1999), equivalent to $0.5 \%$ of US GDP. ${ }^{9}$

A number of other factors may explain the recent improvement in TFP performance, including the strong dollar, unrecorded increased labour, better monetary and fiscal policies, cheap commodities, the strength of Wall Street, low pressure on non-wage labour costs, the Asian crisis or unsustainable corporate and consumer borrowing.

There are many bold predictions for the future. For instance, as a result of developing Internet-based applications for company procedures, Oracle plans to cut US $\$ 2$ billion out of US $\$ 7$ billion of global corporate expenses (The Economist, 11 November 2000). The evidence to date is less reassuring, however. Roberti (2001) notes that savings from companies that moved earlier and more aggressively to the web have been smaller than expected. IBM, for example, bought US $\$ 27.7$ billion dollars of goods electronically in the first three quarters of 2000 and saved only US $\$ 247$ million (less than $1 \%$ ) by doing so. On the sales side, 66 million customer service transactions were handled via IBM.com, but the head-count in call centres has remained exactly the same.

More sober evaluations of the real potential gains to e-commerce might account for the collapse in e-commerce growth-between 1998 and the end of 2000, the FEI/Duke Corporate Outlook Survey (www.duke.edu/ jgraham) suggests that the percentage of sales made online by surveyed companies remained unchanged at $5 \%$.

The micro-level evidence thus suggests that the impact of the Internet to date has been marginal. A specific example of a widely used technology over which the Internet is just a marginal, evolutionary, advance is electronic data interchange (EDI). EDI systems use proprietary software to connect purchasers' and suppliers' computers to automate transaction and processing exchange. Such systems are already estimated to support about US $\$ 3$ trillion in economic activity in the USA. While Internet-based systems are estimated to have operating costs of about $1 \%$ of EDI systems, the cost of conversion to Internet-based systems is itself high enough to have discouraged the bulk of EDI users from so far switching to the Internet (World Bank, 2000a). This suggests that the gain from using the Internet over EDI is not very large. ${ }^{10}$

At the macro level, returns might be even lower because of two negative externalities linked to e-commerce. First, the Internet allows businesses to force customers to perform part of the service previously provided by the newly networked business. For example, Expedia.com encourages customers to search for cheaper flights through the air ticket database rather than its travel agents. This leads to savings for Expedia, but does not necessarily increase efficiency. Second, and of greater concern to LDC companies with less access to the new technologies, there may be high returns to investment by large Internet companies from developed countries in raising market share (for instance, Borders.com against Amazon.com). The social returns to such investment may well be lower than private returns. ${ }^{11}$

There are, therefore, two concerns for LDCs. First, if there is limited evidence of a past spillover impact of investment in computers and the Internet on economic growth in the USA, and the case for a dramatic increase in productivity in the future is at least mixed, any benefits from the Internet in LDCs are likely to be delayed and 
comparatively small. Access to the capital required to use the Internet is very limited in LDCs, present use is a fraction of that in the developed world and this state of affairs is unlikely to change significantly in the short term. In other words, the present level of usage in the USA is not promoting growth, and this level of usage is already far higher than can be expected in developing countries for many years to come.

A second reason for concern is that, in the USA, moving online has become important to protect market share. If this becomes true on a global level, those companies least equipped to move online are likely to lose market share to those better placed. It is likely that the least-equipped companies will be concentrated in the developing world.

\section{The Internet in LDCs}

The production of IT equipment is the one sector of the US economy that has seen undoubted productivity gains. However, it is not a sector that is prevalent in many developing countries. There are exceptions, for instance, high-technology exports account for $28 \%$ of East Asia's manufacturing exports, and India has a thriving IT export industry. However, most LDCs import far more high-technology equipment and services than they export. The ITU estimates that exports of telecommunications equipment are only worth $8 \%$ of imports of such equipment in low-income and $40 \%$ of imports in middle-income countries (ITU, 2000). Overall, low-income countries (excluding the newly industrializing economies) account for only $0.3 \%$ of the world's high-technology exports. LDCs also have far lower expenditures on developing new technologies. R\&D in all low income countries combined totalled approximately US $\$ 5$ billion in 1999 , compared to US R\&D of US $\$ 234$ billion. As a result, the OECD dominates world patent applications. Patent applications numbering 1114408 were filed in low-income countries in 1998. Under 10000 of these applications-or under $1 \%$-were filed by residents. Royalty and licence fee payments by low-income countries were nine times receipts, whereas in the USA, royalty receipts were 2.7 times payments (calculated from World Bank, 2001).

These are significant figures because most of the profits in the IT sector are made by patent owners rather than licencees (suggested by the fact that US companies produce $56 \%$ of the revenues yet garner $96 \%$ of the profits from the global IT industry (Heeks \& Kenny, 2001)). Perhaps because of this, evidence from LDCs with significant IT industries does not suggest a productivity impact of the kind seen in the USA. East Asia, the developing region with the largest IT industry, suggests no correlation between the proportion of high-tech exports in total exports and productivity growth (APEC, 2001). Overall, LDCs are largely importing goods in the IT sectors, not inventing or even producing them. Given this is where the profits and productivity increases of the Internet revolution appear to be concentrated, this is a significant problem.

Turning to potential spillover effects and productivity gains, LDCs also appear to be in a weaker position. First they have less access to the network. Most producers and consumers in the USA had telephone and computer access prior to the expansion of the Internet, making the cost of connection to the Internet (the purchase of a modem and an ISP account) marginal. In LDCs, the picture is markedly different. Telephone lines per capita average 2.6 per 100 people in low-income countries as compared to 66.4 in the USA. Albouy (1999) estimates that about 2 billion people, the vast majority in 
LDCs, lack access to electricity (in rural Tanzania, it is $99.2 \%$ of the population). Computer ownership is 4.4 per 1000 people in low-income economies compared to 511 per 1000 in the USA (calculated from World Bank, 2001).

Further, while technological change is making both network and computer access cheaper, serving LDC populations will remain more expensive than serving OECD populations. Fifty-nine per cent of the population in low- and middle-income countries is rural, compared to $24 \%$ in high-income economies. It is more expensive to provide networked services such as electricity and telecommunications to rural areas because the infrastructure required per customer is higher than in urban areas. The physical costs of computer and telephone access are unlikely to drop below US $\$ 1000$ even in relatively population-dense rural areas with electricity access (Kenny, 2002). In lowdensity areas without networked services, costs of Internet infrastructure can rise as high as US $\$ 20000$ per computer. ${ }^{12}$ Not only is this more than 38 times the average income per capita of low-income countries, it also suggests that Internet infrastructure investments in LDCs will generate lower returns in terms of network access than they do in the OECD. In turn, this suggests lower returns to investment in terms of economic impact.

Physical access is only the first, and perhaps least significant, barrier to the exploitation of the new technology. This is suggested by low Internet usage rates even where access is available in developing countries. For example, Pigato (2000) finds in a survey of Tanzanian firms that computer usage remains very low even in firms that own a computer (only about $20 \%$ had actually computerized basic business functions such as invoicing). Internet use was also low: of the $30 \%$ who had access, less than half used it frequently and only $13 \%$ rated it as an effective product promotion tool. Even in wealthier countries in East Asia, while over 90\% of the populations of Korea, Singapore and Hong Kong know where to access the Internet, only one-third to one-half actually use the technology (calculated from Rose, 2001). ${ }^{13}$

The non-physical costs of Internet use might help to explain these numbers. David (2000) estimates that in the USA only $10 \%$ of the cost of computer ownership to a company is accounted for by the purchase of the physical equipment itself-the other $90 \%$ is made up of factors such as training and support. Where human capital is scarce, these costs are likely to be an even more significant barrier. General education, specific technical and language skills and the broader institutional environment are all factors that might explain low usage rates.

Turning now to education, evidence from both the USA and India suggests that those benefiting most from IT investments are the better educated and more highly skilled, who are being hired in greater numbers and increasing their pay differentials over unskilled, less educated colleagues (Autor et al., 1998; Lal, 1996). The great majority of users in the developing world are from the most educated sector of the population (in Ethiopia, 98\% of Internet users had a university degree in 1998 (CABECA, 1998)). Yet, the stock of "tertiary human capital" in LDCs, on average and as a percentage of US stocks, is about as small as the stock of physical capital (Heeks \& Kenny, 2001). Advanced education, of the greatest value in a "global knowledge economy" is rare in LDCs. Approximately one-third of adults in low-income countries cannot even read - a vital skill for meaningful use of the Internet.

Looking specifically at skills related to the Internet, the technical skills gap is frequently highlighted as at least as serious a barrier to Internet use as the lack of access to the Internet itself $(\mathrm{G}-8,2000)$. The extent to which basic computer skills are lacking in LDCs is suggested by a report from Wa in Northern Ghana that locals trained in computer skills and management could earn US $\$ 6000$ per year-this in a country with 
an average GNP per capita of US $\$ 390$ (Hirsch, 1998). These skills gaps are likely to remain in the population at large-not least because, with per-student discretionary expenditures in secondary schools running as low as US $\$ 12$ a year, the majority of schools in developing countries cannot afford to install IT labs (Grace \& Kenny, 2001).

As important, there is a significant language skills gap, with perhaps half of the populations of the least developed countries not able to speak an official language of their own country-let alone English, the predominant language of the Internet. Language remains a significant barrier to use, as is suggested by a study in Slovenia, which found that $75 \%$ of those who were fluent in English used the Internet compared to only $1 \%$ of non-English speakers (Kenny, 2002). Guillen \& Suarez (2001) found that countries where English is the official or most widely spoken language have significantly higher Internet users per capita. This is hardly surprising, given the quality and quantity of non-English web material. In 1999, 72\% of web sites were in English. Conversely, the number of sites in languages such as Quechua (spoken by 10 million people in Bolivia, Ecuador and Peru) or Ibo (spoken by 15 million in Nigeria) can be counted on the fingers of one hand-and none offer interactive features (Kenny, 2002).

Beyond the scarcity of physical and human capital needed to benefit from the Internet, the institutional environment in LDCs is not conducive to rapid and successful exploitation of the technology. Weak institutional capacity has been found to correlate across countries with lower access to networks and lower host site development (Kenny, 2001; Oxley \& Yeung, 2000). ${ }^{14}$ Weak institutions also lower consumer trust in e-commerce, perhaps the most important factor in determining willingness to purchase online. ${ }^{15}$

Poorly developed financial systems in particular, especially when combined with poor physical communications infrastructure, can significantly reduce the potential for e-commerce in LDCs. For example, a recent survey of business trust in the postal service (Kirkman et al., 2002) found that willingness to entrust the postal network with a package worth US $\$ 100$ was strongly correlated with GNP per capita, with Finland, Japan and Switzerland at the top and Venezuela, Honduras and Nigeria at the bottom. Regarding credit cards, results from Latin America suggest that only $28 \%$ of online transactions in the region use credit cards, compared to 54\% using cash, more a result of lack of trust in than lack of access to the credit card system (Hilbert, 2001). Miller (2001) argues that such weaknesses account for the fact that only $2.2 \%$ of India's Internet subscribers have engaged in e-commerce activities.

The combination of low network rollout, low skills and a poor institutional environment, when combined with network externalities, might leave LDCs stuck in a low-use low-utility trap regarding the Internet. With few employers, customers or suppliers with access to skills, with little relevant (or comprehensible) content, firms and individuals have little incentive to use the technology. With few firms and individuals induced to move online, the utility of the Internet remains low.

There is some evidence that this Internet trap exists in LDCs. Pigato (2000) argues that low IT usage in Tanzania was due in part to entrepreneurs simply not knowing how to make use of it and in part because of scale effects: use was much higher amongst tourism enterprises, where a considerable part of the customer base was likely to be online.

These factors help to explain the extent of the "digital divide" in terms of access to the Internet. Low-income countries account for $40 \%$ of the world's population and $11 \%$ of its gross national income (calculated from World Bank, 2001). ${ }^{16}$ Of 242 million Internet users world-wide in 1999 , only 5 million, or about $2 \%$, were in low-income countries. Of 110498 secure servers world-wide that use encryption technologies in 
Internet transactions (commonly used for e-commerce), only 224 , or $0.2 \%$, are in low-income countries.

Turning to the potential for LDCs to expand trade due to "the death of distance", Venables (2001) suggests that these opportunities are much overrated. Many "knowledge goods" remain embodied in human or physical capital, that is expensive (and difficult) to transport across international boundaries. Venables also notes that as goods become weightless, they also undergo dramatic productivity increases and price reductions. Taking the example of airline ticketing, he notes that the major impact of ICT has been to replace labour by computer equipment and only secondarily to allow remaining workers to be employed in remote locations.

Looking at the type of "low-tech" service jobs that are now exportable, it is doubtful that there are enough to make a significant difference to the developing world as a whole. Data entry (the low-skill end of information processing) is a US\$800 million industry in the USA. If the USA only had a share in the global data entry market equal to its share in global GDP (about $27 \%$ of the world total), the industry world-wide would be worth approximately US $\$ 3$ billion. This is a little less than the annual exports of Estonia (Schware \& Hume, 1996; World Bank, 2000b). More generously, the ILO (2001) reports that perhaps $5 \%$ of all service sector jobs in industrial countries are "contestable" by LDCs-none the less, this totals just 12 million jobs, or $0.24 \%$ of the population of the developing world (Calculated from World Bank, 2001).

The Internet may even act as a tool for greater divergence in incomes between rich and poor. The fact that general technologies are important for growth, and that rich countries today are by and large the countries that were rich 50 or 100 years ago (see Kenny, 1999), suggests that the "average" technology probably has a larger impact on growth prospects in wealthy countries than in poor countries (Heeks \& Kenny, 2001). Venables (2001) also suggests that innovations in communications technologies in the past have further concentrated income in a few geographic areas.

A number of studies based on US and European data also suggest that less advanced companies and regions are benefiting less from the Internet as well, as would be expected if network externalities and low-utility traps were at work. Indeed, the firms that are benefiting most from the introduction of IT are those that were already thriving in the "old economy" (World Bank, 2000a; Doms et al., 1997; Greenan et al., 2001). At the regional level, advanced regions in Europe have also benefited more from the communications infrastructure than less advanced regions (Cornford, 2001). ${ }^{17}$ The production of high value added "knowledge goods" has remained concentrated in wealthier regions in the UK, for example, despite falling communications costs (Cornford, 2001). Finally, "dot.com" firms are also highly concentrated globally, and in regions that were wealthy prior to their creation (Gillespie et al., 2001).

LDCs face high costs to access ICTs, a number of barriers to exploit that access, limited opportunities if those barriers are overcome, and some threat that wider access to ICTs might actually speed divergence. It is perhaps for such reasons that even studies that find a historical link between IT investment and growth in developed countries fail to find such a link in LDCs (see Pohjola, 2001; Mayer, 2000). ${ }^{18}$

\section{Estimates of the Future Impact of the Internet on Economic Growth}

Many businesses and economists are predicting significant savings and productivity increases from moving processes online. There is evidence that much of these savings might be swallowed up by competing for market share, with little impact on the national economy. This paper has presented a range of further arguments for caution 
in predicting a significant positive impact of the Internet on LDC economies. None the less, this section suggests that even the more optimistic analysts of the economic effects of the Internet lay out a scenario of comparatively little impact on the course of divergence, and that evidence from past "revolutions" in transactions costs reductions support this conclusion.

Estimates for OECD countries suggest an impact of e-business on growth as small as one-third of $1 \%$ by 2005 . Taking the USA alone, a more generous estimate by Goldman Sachs is perhaps 5\% by 2010 (The Economist, 1 April 2000). ${ }^{19}$ More optimistic still, it is commonly assumed that investments in telecommunications and IT, which account for the same proportion of today's capital stock as railways did in the late 19th Century (a little over 10\%), will have a similar impact on US economic growth as estimated for railways-around 10\% (although Fogle (1964) estimates the impact for railways at one-third of this figure). If this were gained over the next 20 years, it would be at a rate of a little under $0.5 \%$ per year.

Even assuming such a large growth impact in the USA, there are reasons to believe that the impact of the Internet on growth in LDCs will be much less significant. It is widely accepted that the impact of the Internet on developing countries, at least over the short term, is likely to be smaller than in developed countries, and this paper presents evidence suggesting that the impact will remain muted. The consulting firm e-Marketer estimates that e-commerce revenues of "the Rest of the World" (RoW) (outside North America, Europe and East Asia) will be $2 \%$ of the global total in 2003 - which equals US $\$ 29$ billion. Assuming that $10 \%$ of revenues add to GDP, this suggests that e-commerce will add the equivalent of Guyana's GDP (a poor country with a population of a little under 1 million) to total "RoW" GDP by $2003 .{ }^{20}$ One recent global estimate suggested that, over the longer term, "effective" e-commerce policies could increase Latin America's GDP by about US $\$ 45$ billion-or about $2 \%$. However, the same source provides estimates that are as low as $1.2 \%$ for Latin America and $1 \%$ for Asia (Mann et al., 2000).

These estimates of the income impact of the Internet by ICT optimists are very small compared to the rich-poor gap. The US GNP per capita is about US $\$ 30000$, compared to Sudan's GNP per capita of about US $\$ 300$, a $10000 \%$ difference (World Bank, 2000b). Compare this to the $10 \%$ additional income that the Internet might (most optimistically) provide. ${ }^{21}$

These figures should, perhaps, not come as a surprise. Despite sharing the networking and transactions-reducing features of the Internet, and despite less demanding human and physical capital requirements, it appears that telecommunications has also had a fairly limited growth impact. ${ }^{22}$ Although there is some econometric evidence that increasing access to telecommunications has an impact on future growth rates, the size and geographical extent of that impact is arguable. The articles by Roller \& Waverman (2001), Canning (1997) and Madden \& Savage (1998) are three recent studies that find some sort of link (although Roller and Waverman only find that link in more advanced economies), Holtz-Eakin (1993, 1994) and Garcia-Mila \& McGuire (1992) dispute it. Even if there is a link, it is unlikely to be significant. Over the last 40 years-and particularly since the spread of mobile telephones-poor countries have seen a far more rapid growth in telephone networks than have developed countries. None the less, there has been a divergence in income between rich and poor countries over the last 40 years, and LDC growth rates have slowed even as networks have expanded (calculated by the author from World Bank, 2001). ${ }^{23}$ As suggested at the start of this paper, the impact of one new invention, however impressive that invention, is likely to be small. 


\section{Conclusion}

This paper has taken a narrow look at the likely impact of the Internet on development. It should be remembered that even this narrow look suggests that there will be significant changes in the way business is done in LDCs - changes that have already begun. The same transactions savings that are available in developed counties from the Internet are available in LDCs. For example, Reliance Industries, a chemical firm in India, has linked its major customers through an Internet-based market exchange, reducing receivables delays by two-thirds and speeding order deliveries (Miller, 2001). More broadly, the technology offers exciting possibilities in education delivery, for health services or for the access of the poor to the tools of governance.

Much of the analysis in the paper has been "static", looking at the direct impact of the Internet on the costs of doing business, not the knock-on effects that the technology might have on creating new business models, or through its support for the development of a better-educated workforce. The Internet is a powerful technology that will have a long-term impact on the quality of life in developing countries.

Having said that, in the past our record in predicting the dynamic impact of technologies on development has been very weak. To take three communicationsrelated examples, the railway was predicted to spark the dictatorship of the proletariat, the telegraph to engender world peace and the television to revolutionize education. While the role of technology in economic growth cannot be questioned, the dynamic impact of a particular, invented technology is never very large. It looks increasingly as if the impact of the computer on US productivity will be a good example of this. The impact has been limited so far, and might not increase in the future.

Hard choices should be made on the basis of our comparative ignorance of the potential impact of the Internet. For example, if the Internet is considered necessary to ensure that businesses remain internationally competitive, should government policy focus on ensuring business access at the cost of equitable access? Similarly with education: if exploiting the Internet requires tertiary education, should governments rechannel resources from primary education for the many to university funding for the few? I would argue that, given the limited evidence of benefits, the great state of uncertainty and the immediate equity costs of such actions, the answer should be to support equitable access and primary education.

Overall, the largest determinant of the impact of the Internet in developing countries is likely to remain the broader environment outside the information infrastructure sector. This environment will also play by far the predominant role in determining the quality of life of LDC populations. For this reason, Microsoft Chairman Bill Gates's argument about the place of direct support to the Internet in development priorities might well be correct: "I am suggesting that if somebody is interested in equity that you wouldn't spend more than 20 percent of your time talking about access to computers, that you'd get back to literacy and health and things like that. So the balance that makes sense is that more money should be spent on malaria" (Gates, 2000). ${ }^{24}$

\section{Notes}

1. The views expressed in this paper are the author's own, and do not necessarily represent the views of the World Bank, its executive directors, or the countries that they represent.

2. For example, cross-country econometric evidence on the impact of the Internet on economic growth or firm productivity is sparse to non-existent, given the fact that the technology is so young. Altig \& Rupert (1999) try a novel approach, estimating the impact of 1999 Internet users as a percentage of population on GDP growth between 1974 and 1992 controlling for 
1950 income per capita (from this, they estimate that $100 \%$ Internet usage would be associated with about $4 \%$ per annum additional economic growth). However, concerns over the direction of causality in this study cast doubt on their conclusions.

3. "Technology" as defined by TFP depends on assumptions made about the importance of various factors to output, and different assumptions can dramatically alter its magnitude. Depending on what is defined as "physical capital" or "labour stock", how the growth of the stock of physical or human capital is measured, whether "natural capital" or "social capital" are included, what (if any) allowances are made for technological change "embodied" in capital investment or market failures such as scale effects, whether capital can be substituted for labour, the share assigned to human over physical capital in output estimates and so on, there can be markedly different estimates for the TFP residual. For example, one recent study looked at the impact of changing just two assumptions on long-term TFP growth in Korea, and produced estimates of annual growth 1960-97 that ranged between 3.0\% of GDP and-1.4\% (these were assumptions about returns to scale and shares of physical and human capital) (Ghosh \& Kraay, 2000). This sensitivity is why the role of technology in growth in regions like East Asia remains hotly debated. Felipe (1999) concludes his survey of TFP growth and capital accumulation in East Asia by noting "this work has become a war of figures ... It seems that re-working the data one can show almost anything".

4. One reason that $\mathrm{R} \& \mathrm{D}$-based technologies like the Internet may not be a central or direct cause of economic growth is that the number of scientists and engineers employed in $R \& D$ in the USA has increased fivefold over 1950-90, while US growth rates have fallen over that period (Keely \& Quah, 1998).

5. Greenan et al. (2001) find no evidence of increasing computerization and R\&D over time having a significant impact on firm performance.

6. Even this revival within the durable goods sector is in part the result of measurement bias (see Schreyer, 2000).

7. Gross product originating per worker in IT-using goods and services fell by an average of $0.1 \%$ over $1990-97$, compared to a $1.1 \%$ rise in non-IT intensive industries (Department of Commerce, 1999).

8. See also Stiroh (1998) for a similar result.

9. The productivity impact was also too late to be credited to straightforward investment in ICT equipment. Already, by $1990,28 \%$ of business expenditure on equipment was on hardware. Overall, corporations spent US $\$ 1.1$ trillion on computer hardware between 1990 and 1996, yet productivity grew by only 0.8\% per year (Perkins \& Perkins, 1999). The slowing of growth in the nominal share of computers in the economy suggests a declining marginal return to computer ownership coinciding with the expansion of the Internet. The nominal share of computer hardware in the economy rose rapidly before 1997. Growth since 1997 has continued the unit-elastic response to the decline in computer prices prevalent prior to 1995-the share of nominal spending on computers has been stable since 1997 (Gordon, 2000). Recent figures suggest that growth might have slowed even below that.

10. To take an example on the B2C (business to consumer) side, forecasters' estimates for B2C e-commerce growth suggest that it might reach $10 \%$ of the total retail market by 2003 -still less than today's share of mail-order catalogues (Almasy \& Wise, 2000).

11. Winners in the battle for market share become "supersites", dominating the web. This has already occurred in the case of news sites, where the top three sites (MSNBC, CNN and the New York Times) account for $72 \%$ of all news site visits on the web (New York Times, 29 August 2001).

12. These are the costs reached in a rural access programme in Costa Rica discussed by Shakeel et al. (2001).

13. As a further example regarding more advanced use of the Internet, connection is already common in Argentine and Chilean firms-60\% of (non-micro) enterprises in Chile are connected to the Internet as well as $87 \%$ of Argentina's small and medium enterprises. None the less, only $15 \%$ of Chilean firms have their own web site and only $20 \%$ of Argentine firms have bought goods online (Hilbert, 2001).

14. Guillen \& Suarez (2001) also find that a "democracy index" is significantly correlated with Internet users and hosts per capita after allowing for a range of other factors.

15. Jupiter Communications (2001) found that four of the top five selection criteria for online purchases were connected with recognition, trust or experience of the retailer-in fourth place was "I can find bargains".

16. The quality of that access is also significantly lower- $-44 \%$ of Brazil's Internet connections 
run at $33 \mathrm{kbps}$, for example, response time is four times longer in Latin America than in the US and packet loss three times higher (McKinsey \& Co., 2001).

17. Greenan et al. (2001), for example, found that while there is no relationship between increasing expenditure on $\mathrm{R} \& \mathrm{D}$ and computerization and French firm performance, firms that perform better tend to have higher R\&D and computing expenditure.

18. Bedi's (1999) survey on this topic could find only one study with a significant result, which found a positive relationship that was likely to be plagued by an endogeneity bias.

19. Forrester research predicts that, by 2003 , e-business will reach US $\$ 1.5$ trillion, or equal to about $13 \%$ of US GDP. If we assume the value added by this business being conducted online is $10 \%$, this would increase the country's GDP by $1.3 \%$ (The Economist, 30 October 1999). The OECD is less positive in its estimates. Its most generous forecast is that, for the whole of the OECD in 2005, e-commerce will equal US $\$ 1$ trillion (Nevens, 1999). Again, assuming a $10 \%$ impact on value added, this suggests that, by 2005 , the OECD will have increased GDP thanks to e-commerce by about one-third of $1 \%$. (See also The Economist Survey: The New Economy, 23 September 2000; World Bank, 2000a.)

20. A third study by Goldman Sachs (2000) estimates that online commerce outside North America, Europe and Asia will generate gross revenues of US $\$ 59$ billion by 2003 , rising to US $\$ 178$ billion by 2005 .

21. World Development Indicators.

22. A similar story can be told for the railways. Fogel's (1964) study of the impact of the railway on the US economy estimates that the level of per capita income reached in the USA on 1 January 1890 would have been reached by 31 March 1890 if railways had never been invented. The problem here, as frequently noted, is that Fogle only looked at the static rather than the dynamic impact of the railway on the US economy-and those dynamic impacts could have been large, even if they are hard to measure.

23. Regarding the role of reduced transactions costs in making LDCs more competitive in trade, evidence regarding progress in international trade talks suggests that this is not enough to spark LDC growth. Assuming generously that the Internet might reduce transactions costs on goods and services by perhaps $10 \%$ (see Goldman Sachs, 2000), compare this to the scale of changes in "institutional technology" over the past 40 years. Looking at the impact of the GATT and WTO trade rounds, for example, average tariffs in industrial countries fell from $40 \%$ in 1947 to $5 \%$ in 1988 - and have fallen further since (Law fournal Extra, 1996). Falling transport costs and more rapid transport systems might have added a further $10 \%$ cost reduction on top of this (Hummels, 1999, 2001). Despite (or perhaps because of) such dramatic improvements, LDC income growth has fallen over that period, and fallen even further behind that of developed countries, suggesting that reduced transactions costs alone will not allow LDCs to close the gap.

24. From within the development community, Amartya Sen notes similar scepticism regarding Bangalore's software export industry: "even 100 Bangalores would not solve India's poverty and deep-seated inequality. For this to happen many more people must participate in growth. This will be difficult to achieve across the barriers of illiteracy, ill health and inequalities in social and economic opportunities" (quoted in Oxfam, 2000)

\section{References}

Albouy, Y. (1999) Institutional reform, in: E. McCarthy \& F. Martin (Eds) Energy and Development Report, 1999: Energy After the Financial Crisis (Washington, DC, World Bank).

Almasy, E. \& Wise, R. (2000) E-venge of the incumbents: a hybrid model for the Internet economy, Ivey Business fournal, 64, pp. 16-19.

Altig, D \& Rupert, P. (1999) Growth and the Internet: Surfing to prosperity? Federal Reserve Bank of Cleveland, Economic Commentary, September.

APEC (Asia-Pacific Economic Co-operation) (2001) The New Economy and APEC (Singapore, APEC).

Autor, D., Katz, L. \& Kreuger, A. (1998) Computing inequality: Have computers changed the labor market?, Quarterly fournal of Economics, 113, pp. 1169-1214.

Bank of England (1999) Inflation Report, Summer (London, Bank of England).

Bedi, A. (1999) The Role of Information and Communication Technologies in Economic Development: A Partial Survey, ZEF Discussion Papers on Development Policy, No. 7, Bonn. 
Bloom, D. \& Sachs, J. (1998) Geography, demography, and economic growth in Africa, Brookings Papers on Economic Activity, 2, pp. 207-295.

Brynjolfsson, E. \& Smith, M. (2000) Frictionless commerce? A comparison of Internet and conventional retailers, Management Science, 46, pp. 563-585.

CABECA (1998) (Menou, M.J.) Connectivity in Africa: use, benefits and constraints of electronic communication, Synthesis Report, Part 2: Overview of the findings of the project. Study carried out under the CABECA project of Padis as part of the IDRC sponsored research programme on the Impact of Information on Development, Addis Ababa, UNECA/PADIS, May.

Canning, D. (1997) Does Infrastructure Cause Economic Growth? International Evidence for Infrastructure Bottlenecks (Harvard Institute for International Development), mimeo.

Cornford, J. (2001) The Evolution of the Information Society and Regional Development in Europe (University of Newcastle), mimeo.

David, P. (2000) Digital Technology and the Productivity Paradox: After Ten Years, What Has Been Learned (Stanford University), mimeo.

Department of Commece (US) (1999) The Emerging Digital Economy II (Washington, DC, Department of Commerce).

Doms, M., Dunne, T. \& Troske, K. (1997) Workers wages and technology, Quarterly fournal of Economics, 112, pp. 253-290.

Felipe, J. (1999) Total factor productivity in East Asia: a critical survey, fournal of Development Studies, 35, No. 4.

Fogle, R.W. (1964) Railroads and Economic Growth: Essays in Economic History (Baltimore, Johns Hopkins).

Fukuyama, F. (1995) Trust: The Social Virtues and the Creation of Prosperity (New York, Free Press).

G-8 (2000) Okinawa Charter on Global Information Society, http://www.oneworld.net/anydoc2.cgi?url

$=\mathrm{http} \% 3 \mathrm{~A} \% 2 \mathrm{~F} \% 2 \mathrm{Fwww} \% 2 \mathrm{Eg} 8 \mathrm{kyushu} \% 2 \mathrm{Dokinawa} \% 2 \mathrm{Ego} \% 2 \mathrm{Ejp} \% 2 \mathrm{Fe} \% 2 \mathrm{Fdocuments} \% 2 \mathrm{~F}$ it $1 \% 2 \mathrm{Ehtml}$

Garcia-Mila, T. \& McGuire, T.J. (1992) The contribution of publicly provided inputs to states' economics, Regional Science and Urban Economics, 22, pp. 229-241.

Gates, W.H. (2000) Speech given at the Digital Dividends conference in Seattle, 18 October, http://www.microsoft.com/billgates/speeches/2000/10-18digitaldividends.asp.

Ghosh, S. \& Kraay, A. (2000) Measuring growth in total factor productivity, World Bank PREM Notes Number 42, September.

Gillespie, A., Richardson, R. \& Cornford, J. (2001) Regional development and the new economy, EIB Papers, 6, pp. 109-131.

Goldman Sachs (2000) B2B - Just How Big is the Opportunity?, available at http://www.gs.com/ hightech/research

Gordon, R. (2000) Does the new economy measure up to the great inventions of the past?, Fournal of Economic Perspectives, 14, p. 4.

Grace, J. \& Kenny, C. (2001) A Short Review of Information and Communications Technologies and Basic Education in LDCs (Washington, DC, World Bank), mimeo.

Greenan, N., Mairess, J. \& Topiol-Bensaid, A. (2001) Information technology and research and development impacts on productivity and skills, in: M. Pohjola (Ed.) Information Technology, Productivity and Economic Growth (Oxford, Oxford University Press).

Guillen, M. \& Suarez, S. (2001) Developing the Internet: entrepreneurship and public policy in Ireland, Singapore, Argentina and Spain, Telecommunications Policy, 25, pp. 349-371.

Heeks, R. \& Kenny, C. (2001) Is the Internet a Technology of Convergence of Divergence? (Washington, World Bank), mimeo.

Hilbert, M. (2001) Latin America on its Path into the Digital Age: Where are We? (Santiago, Chile, CEPAL/ECLAC).

Hirsch, A. (1998) Computer Training and Internet Access Issues in Wa, Upper West Province, Ghana (Washington, World Bank), mimeo.

Holtz-Eakin, D. (1993) State-specific estimates of state and local government capital, Regional Science and Urban Economics, 23, pp. 185-209.

Holtz-Eakin, D. (1994) Public-sector capital and the productivity puzzle, The Review of Economics and Statistics, 76, pp. 12-21.

Hummels, D. (1999) Have International Transportation Costs Declined? (Chicago, University of Chicago), mimeo. 


\section{C. Kenny}

Hummels, D. (2001) Time as a Trade Barrier (Chicago, University of Chicago), mimeo.

ILO (2001) World Employment Report (Geneva, ILO).

ITU (International Telecommunications Union) (2000) World Telecommunications Indicators (Geneva, ITU).

Keely, L. \& Quah, D. (1998) Technology and Economic Growth (London, LSE), mimeo.

Kenny, C. (1999) Why aren't countries rich? Weak states and bad neighborhoods, fournal of Development Studies, 35, pp. 26-47.

Kenny, C. (2002) Information and communications technologies for direct poverty alleviation: costs and benefits, Development Policy Review, 20, 2, pp. 141-157.

Kenny, C. \& Williams, D. (2001) What do economists know about economic growth-or why don't they know very much?, World Development, 29 No. 1.

Kirkman, G., Cornelius, P., Sachs, J. \& Schwab, K. (Eds) (2002) The Global Information Technology Report 2001-2002 (New York, Oxford University Press).

Lal, K. (1996) Information technology, international orientation and performance: a case study of electrical and electronic goods manufacturing firms in India, Information Economics and Policy, 8, pp. 269-280.

Law Fournal Extra (1996) A history of GATT and the structure of the WTO, International Contract Adviser, II, No. 1.

Lehr, B. \& Lichtenberg, F. (1999) Information technology and its impact on productivity: firm-level evidence from government and private data sources, 1977-1993, Canadian fournal of Economics, 32, pp. 335-362.

Madden, G. \& Savage, S.J. (1998) CEE telecommunications investment and economic growth, Information Economics and Policy, 10, pp. 173-195.

Mann, C., Eckert, S. \& Knight, S. (2000) Global Electronic Commerce (Washington, DC, International Institute for Economics).

Mayer, J. (2000) Globalization, Technology Transfer and Skill Accumulation in Low-income Countries, WIDER Working Paper No. 150.

McKinsey \& Co. (2001) Fulfillment to Consumers in Emerging Economies, presentation, 20 June.

Miller, R. (2001) Leapfrogging? India's Information Technology Industry and the Internet, IFC Discussion Paper No. 42.

Nevens, T.M. (1999) The mouse that roared, The McKinsey Quarterly, 1, pp. 145-148.

Nezu, R. (2000) E-Commerce: A Revolution with Power (Paris, OECD), mimeo.

Oxfam (2000) Education Now: Break the Cycle of Poverty (Oxford, Oxfam), available at http:// www.caa.org.au/oxfam/advocacy/education/report

Oxley, J. \& Yeung, B. (2000) E-Commerce Readiness: Institutional Environment and International Competitiveness (University of Michigan Business School), mimeo.

Perkins, A. \& Perkins, M. (1999) Eyes wide shut, Financial Planning, 1 December.

Pigato, M. (2000) Information and Communication Technology, Poverty and Development in sub-Saharan Africa and South Asia (Washington, DC, World Bank), mimeo.

Pohjola, M. (2001) Introduction, in: M. Pohjola (Ed.) Information Technology, Productivity and Economic Growth (Oxford, Oxford University Press).

Pohjola, M. (1998) Information Technology and Economic Development: An Introduction to the Research Issues, UNU WIDER Working Paper 153.

Roberti, M. (2001) General Electric's spin machine, The Industry Standard, 22-29 January.

Roller, L.-H. \& Waverman, L. (2001).Telecommunications infrastructure and economic development: a simultaneous approach, American Economic Review, 91, pp 909-923.

Romer, P. (1990) Are Nonconvexivities Important for Understanding Growth?, NBER Working Paper, No. 3271.

Rose, R. (2001) Openness, impersonal and continuing accountability: the Internet's prospective impact on East Asian governance, background paper for S. Yusuf (Ed.) East Asia's Future Economy (Washington, DC, World Bank).

Schreyer, P. (2000) The Contribution of Information and Communications Technology to Output Growth: A Study of the G7 Countries, OECD STI Working Paper DSTI/DOC(2000)2, Paris.

Schware, R. \& Hume, S. (1996) Prospects for Information Services Exports from the English-Speaking Caribbean (Washington, DC, World Bank), mimeo.

Shakeel, H., Best, M., Miller, B. \& Weber, S. (2001) Comparing urban and rural telecenters' cost, The Electronic Fournal on Information Systems in Developing Countries, 4, pp. 1-13.

Stiroh, K. (1998) Computers, productivity and input substitution, Economic Enquiry, 36, pp. 175191. 
Venables, A (2001) Geography and International Inequalities: the Impact of New Technologies (London, London School of Economics), mimeo.

World Bank (2000a) Global Economic Prospects (Washington, DC, World Bank).

World Bank (2000b) World Development Indicators (Washington, DC, World Bank).

World Bank (2001) World Development Indicators (Washington, DC, World Bank).

Yusuf, S. (2000) East Asia's Future: A Project Outline (Washington, DC, World Bank), mimeo. 